\title{
Występowanie szumów usznych u dzieci - przegląd piśmiennictwa
}

\section{Tinnitus in children - literature review}

\author{
Danuta Raj-Koziak \\ Instytut Fizjologii i Patologii Słuchu, Światowe Centrum Słuchu, Klinika Audiologii i Foniatrii, \\ Warszawa/Kajetany
}

Adres autora: Danuta Raj-Koziak, Światowe Centrum Słuchu, Klinika Audiologii i Foniatrii, ul. Mokra 17, Kajetany, 05-830 Nadarzyn, e-mail: d.koziak@ifps.org.pl

\section{Streszczenie}

W ciągu ostatnich kilkudziesięciu lat szumy uszne stały się przedmiotem zainteresowania audiologów oraz laryngologów. Szczegółowej analizie podano częstość występowania tego problemu. W niniejszym opracowaniu przedstawiono wyniki większości opublikowanych dotychczas badań oceniających częstość występowania szumów usznych u dzieci. Wyniki te nie są tak jednoznaczne jak w populacji osób dorosłych i różnią się między sobą w szerokim zakresie, co nie pozwala na zajęcie jednoznacznego stanowiska w tej kwestii.

Słowa kluczowe: szumy uszne • częstość występowania • dzieci

\begin{abstract}
Over the past several years due to increasing number of patients seeking help, diagnosis and treatment, tinnitus has become of interest of audiologists and otolaryngologists. As a result of this the prevalence of the issue has been subjected to a thorough analysis. In the present work the authors present results of most of the already published research assessing prevalence of tinnitus in children. The results of the research on prevalence of tinnitus in children are not so obvious, they vary significantly. This does not allow us to take a clear position on the issue.
\end{abstract}

Key words: tinnitus $\bullet$ prevalence $\bullet$ children

\section{Wstęp}

W ciągu ostatnich kilkudziesięciu lat szumy uszne stały się, ze względu na wzrastającą liczbę pacjentów zgłaszających się do diagnostyki, przedmiotem zainteresowania audiologów oraz laryngologów. Szczegółowej analizie podano częstość występowania tego problemu. Dokładne rozpoznanie skali występowania szumów usznych w populacji dziecięcej wydaje się istotne, gdyż ich występowanie może być niedoszacowane. Większość autorów wyraża pogląd, że zebranie wywiadu z dzieckiem na temat szumów usznych jest trudne ze względu na fakt, że dzieci odpowiadają na pytania w różny sposób. Mogą chcieć pomóc pytającemu i wtedy na wszystkie pytania będą odpowiadać pozytywnie (tzw. overreporting) lub odwrotnie - mogą czuć się zdezorientowane, speszone pytaniami i odpowiadać negatywnie (tzw. underreporting) [1]. Dzieci zapytane bezpośrednio o problem szumów usznych potrafią bardzo dokładnie opisać symptom, natomiast same spontanicznie rzadko go zgłaszają [2]. Rozbieżność pomiędzy dość częstym występowaniem szumów usznych w populacji pediatrycznej i nieczęsto zgłaszanymi skargami na szumy uszne próbuje się tłumaczyć tym, że dzieci, doświadczając stałych szumów usznych przez długi czas, uznają je za zjawisko normalne. Ponadto uważa się, że dzieci odczuwające szumy uszne nie zdają sobie sprawy z faktu, że obecność tej dolegliwości ma istotne znaczenie medyczne. Dzieci, w przeciwieństwie do dorosłych, angażując się znacznie w odbiór bodźców ze środowiska zewnętrznego, potrafią łatwo odwrócić swoją uwagę od szumów usznych [2]. Baquley uważa, że dzieci nie zgłaszają problemu szumów usznych, ponieważ nie osiągają takiego poziomu dojrzałości, aby podzielić się problemem z rówieśnikami [1].

\section{Cel}

Celem niniejszego opracowania było przedstawienie wyników badań dotyczących częstości występowania szumów usznych u dzieci na podstawie przeglądu piśmiennictwa.

\section{Przegląd piśmiennictwa}

Thomas jako pierwszy podjął temat szumów usznych u dzieci w 1938 r., zaprzeczając ich istnieniu. Tłumaczył 
to mniejszą gęstością kości skroniowej u dziecka i stałym ciśnieniem endolimfy [3]. Pacjent 15-letni odczuwający szumy uszne został opisany przez Venters w 1953 r. [4]. W latach 60. XX wieku Reed przeprowadził badania na grupie 200 pacjentów z subiektywnymi szumami usznymi. Opisał dwa przypadki występowania szumów u osób w wieku poniżej 20 roku życia [5].

Nodar uznawany jest za pierwszego autora, który zajął się problemem szumów usznych u dzieci. W 1972 r. przeprowadził badania kwestionariuszowe oceniające występowanie szumów usznych wśród 2000 dzieci w wieku od 10 do 18 lat. Pytając o słyszenie dźwięków w uszach, takich jak: dzwonienie, brzęczenie czy trzaski, ustalił, że 13,3\% prawidłowo słyszących nastolatków doświadcza tych dolegliwości. Natomiast wśród dzieci z niedosłuchem występowanie szumów usznych stwierdził u 58,6\% z nich. Szumy częściej występowały w grupie dzieci z niedosłuchem umiarkowanym niż wśród dzieci głęboko niedosłyszących [6].

Dziewięćdziesięcioro troje niedosłyszących dzieci uczęszczających do szkół masowych zostało zapytanych przez Millsa o obecność szumów usznych. Dwadzieścia dziewięć procent badanych potwierdziło obecność tej dolegliwości, a jedna trzecia dzieci zgłosiła dokuczliwe szumy uszne. Występowanie szumów usznych w tej grupie uczniów zostało porównane z grupą 109 dzieci z problemami usznymi, które zapytano o obecność szumów usznych. Wśród badanych $38,5 \%$ zgłosiło ich słyszenie. W cytowanej publikacji przedstawiono również wyniki danych uzyskanych od dzieci będących pacjentami kliniki otolaryngologii dziecięcej. Wywiad z dziećmi z problemami usznymi został zebrany przez lekarzy laryngologów. W czasie trwania badań zarejestrowano odpowiedzi 403 dzieci, z których trzynaścioro $(3,0 \%)$ zgłosiło szumy uszne spontanicznie. U każdego pacjenta stwierdzono w czasie konsultacji chorobę uszu. Występowanie szumów usznych w tej grupie badanych było znacząco wyższe niż u dzieci, u których w czasie wizyty nie stwierdzono nieprawidłowości w uszach [7].

Graham w 1987 r. opublikował wyniki badań przeprowadzonych w grupie 158 niedosłyszących dzieci w wieku od 12 do18 lat, uczęszczających do szkół masowych z wydzielonymi oddziałami dla niedosłyszących (92 uczniów) oraz dzieci uczęszczających do szkół dla głuchych (66 uczniów). Dzieci odpowiadały na dziewięć pytań zawartych w kwestionariuszu podstawowym, dotyczących lokalizacji, charakteru, czasu trwania oraz dokuczliwości odczuwanych szumów usznych. Siedem pytań dodatkowych pozwoliło na uzyskanie szczegółowych informacji na temat: częstości występowania szumów usznych, czasu ich trwania, głośności, współistniejących zaburzeń równowagi oraz wpływu szumów usznych na rozumienie mowy. Występowanie szumów usznych stwierdzono u 49\% uczniów. Większość dzieci, z wyjątkiem dwojga, zgłosiła obecność szumów okresowych. Dokuczliwe szumy uszne deklarowało $31 \%$ badanych. $U$ trojga dzieci stwierdzono szumy uszne obiektywne [8].

Viani zebrał wywiad na temat słyszenia szumów usznych od 102 dzieci w wieku od 6 do 17 lat. U większości z nich występował głęboki niedosłuch. Obecność szumów usznych w grupie badanej stwierdził u 23,5\% [9]. Drukier w tym samym roku po przebadaniu 331 głęboko niedosłyszących dzieci u 33,0\% z nich stwierdził obecność szumów usznych [10].

Zwraca się uwagę na trudności w zbieraniu wywiadu na temat obecności szumów usznych występujące znacznie częściej u dzieci niż u dorosłych. Aby zwiększyć wiarygodność odpowiedzi, Stouffer do badań zakwalifikował grupę 161 dzieci, które zanim zostały zapytane o obecność szumów usznych, udzielały również odpowiedzi na pytania niezwiązane $\mathrm{z}$ występowaniem szumów usznych. Badaną grupę tworzyły dzieci w przedziale wiekowym od 7 do 12 lat, które odpowiadały na pytanie następującej treści: Czy słyszysz hałas w głowie trwający dłużej niż 5 minut? Autor zadawał dzieciom również pytania niezwiązane z odczuwaniem szumów, pragnąc sprawdzić spójność ich odpowiedzi. W grupie dzieci prawidłowo słyszących, które równocześnie udzielały prawidłowej odpowiedzi na pytania niezwiązane z odczuwaniem szumów usznych, obecność szumów usznych stwierdzono u 6\% badanych. Wśród badanych dzieci, które udzielały nieprawidłowej odpowiedzi na dodatkowe pytania sprawdzające, częstość występowania szumów usznych oceniono na poziomie $13 \%$. Częstość występowania szumów usznych wśród badanych ze współistniejącym niedosłuchem w zależności od wyników odpowiedzi na pytania dodatkowe wyniosła odpowiednio $24 \%$ i $29 \%$ [11].

W piśmiennictwie polskim po raz pierwszy tematykę szumów usznych u dzieci podjęła Bartnik, opisując w $2000 \mathrm{r}$. występowanie szumów usznych i nadwrażliwości słuchowej [12]. Borawska w kolejnych latach kontynuowała pracę związaną z diagnostyką i leczeniem szumów usznych i zaproponowała w 2003 r. procedurę diagnostyki i terapii szumów usznych u dzieci w Polsce [13].

Anst w 2002 r. w Niemczech zebrał wywiad na temat obecności szumów u 1420 dzieci w wieku od 7 do12 lat. Szumy uszne stwierdzono u $7 \%$ badanych. Stałe szumy uszne odczuwało $1,2 \%$, a szumy okresowe $5,8 \%$ pacjentów [14].

Holgers przeprowadziła badania epidemiologiczne związane $\mathrm{z}$ występowaniem szumów usznych u dzieci w Szwecji w 2003 r. Dzieci w wieku 7 lat udzielały odpowiedzi na pytanie zawarte $\mathrm{w}$ kwestionariuszu o następującym brzmieniu: Czy po słuchaniu głośnej muzyki lub innych głośnych dźwięków słyszysz dzwonienie, brzęczenie lub inne dźwięki w uszach? Wśród 964 badanych 12\% dzieci zgłosiło obecność szumów usznych. U dzieci z prawidłowym wynikiem badania słuchu występowanie szumów usznych oceniono na poziomie $13 \%$, natomiast wśród dzieci $\mathrm{z}$ niedosłuchem w przeciwieństwie do większości autorów stwierdzono mniejszy odsetek występowania szumów usznych - na poziomie $8,8 \%$ [15]. Juul w badaniach przeprowadzonych w 2012 r. również w Szwecji stwierdziła występowanie szumów usznych wśród $27 \%$ dzieci 7-letnich prawidłowo słyszących i u 50\% dzieci z niedosłuchem [16].

Wyniki badań przeprowadzonych przez Coelho w Brazylii w 2007 r. w grupie dzieci w wieku od 5 do 12 lat wykazały, że szumów usznych doświadcza $37 \%$ badanych. Wśród dzieci z niedosłuchem częstość występowania szumów wyniosła $18,5 \%$, identycznie jak w grupie dzieci z prawidłowym słuchem. Wyniki uzyskano, zadając dzieciom pytanie, czy słyszą hałas w głowie lub w uszach. Dzieci zostały 
również poproszone o ocenę dokuczliwości odczuwanych przez nie dźwięków. Szumy uszne jako dokuczliwe oceniło $19 \%$ dzieci $z$ prawidłowym słuchem oraz $17,8 \%$ dzieci niedosłyszących [17].

W tym samym roku Savastano opublikowała wyniki badań epidemiologicznych przeprowadzonych we Włoszech. Dane uzyskane od 1100 dzieci w wieku od 6 do 16 lat zostały zebrane na podstawie wywiadu. Występowanie szumów usznych oceniono na poziomie $34 \%$. Tylko $6,5 \%$ dzieci zgłosiło problem spontanicznie, pozostałe potwierdziły słyszenie szumów dopiero, gdy zostały o nie bezpośrednio zapytane [2].

Badania oceniające występowanie szumów usznych u dzieci w Turcji zostały opublikowane przez Aksoya. Grupa badana to 1020 dzieci w wieku od 6 do 16 lat. Odpowiedzi na temat występowania szumów usznych zostały zebrane na podstawie wyników danych kwestionariuszowych. Odsetek dzieci zgłaszających stałe szumy uszne wyniósł 15,1\%. $\mathrm{W}$ tej grupie szumy uszne ciągłe zgłosiło $7,1 \%$, szumy uszne słyszane przez większą część dnia podało 9,7\% dzieci, a szumy słyszane tylko czasami $83,1 \%$ badanych [18].

Wyniki innych badań epidemiologicznych przeprowadzonych również w Turcji w 2009 r. wykazały, że 33,4\% dzieci doświadcza szumów usznych, z czego $35,2 \%$ wskazuje jako ich przyczynę słuchanie bardzo głośnej muzyki. Grupa badana obejmowała 428 dzieci, w tym dzieci w wieku od 11 do 13 lat uczęszczające do szkół podstawowych, grupę młodzieży gimnazjalnej w wieku od 13 do 15 lat oraz grupę licealistów w wieku od 16 do 18 lat. Szumy uszne najczęściej występowały wśród młodzieży gimnazjalnej $(36,8 \%)$, nieco rzadziej wśród uczniów szkół podstawowych $(33,5 \%)$. W grupie licealistów stwierdzony odsetek dzieci odczuwających szumy uszne był najniższy i wyniósł 31,5\% [19].

W Polsce w 2011 r. opublikowano wyniki badań ankietowych na temat występowania szumów usznych. Badania przeprowadzone zostały przez Instytut Fizjologii i Patologii Słuchu w trakcie realizacji Programu Powszechnych Przesiewowych Badań Słuchu. Przebadano 55201 dzieci w wieku 7 lat, zamieszkujących na terenie Polski wschodniej obejmującym województwa: warmińsko-mazurskie, podlaskie, mazowieckie, lubelskie, świętokrzyskie, małopolskie i podkarpackie. Na podstawie odpowiedzi ankietowych uzyskanych od rodziców stwierdzono, że u 12,8\% dzieci zamieszkujących małe miasta i wsie występują szumy uszne. Tylko $1,3 \%$ odpowiedzi rodziców wskazywało na częste i bardzo częste słyszenie szumów usznych przez ich dzieci. Odsetek odpowiedzi pozytywnych na pytanie o odczuwanie szumów usznych uzyskanych bezpośrednio od dzieci był znacznie wyższy w porównaniu z wynikami uzyskanymi od rodziców i wyniósł 31,6\% [20].

Kontynuacja badań słuchu wśród dzieci szkolnych z regionu Polski zachodniej podczas realizacji programu Powszechnych Przesiewowych Badań Słuchu pozwoliła na zebranie danych ankietowych na temat częstości występowania szumów usznych wśród 118005 7-latków zamieszkujących małe miasta i wsie w całej Polsce oraz wśród 23 339 12-latków mieszkających w Warszawie. W celu oceny częstotliwości występowania szumów usznych wśród dzieci 7- i 12-letnich wykorzystano odpowiedzi rodziców na pytanie: „Czy dziecko skarży się na występowanie szumów usznych, gdy jest cicho?". Natomiast w dniu wykonywania badania przesiewowego słuchu w szkole dzieci odpowiadały na pytanie z części ankiety przeznaczonej dla nich: „Czy zdarza Ci się słyszeć w uszach szumy, piski lub gwizdy, gdy zasypiasz i jest cicho w pokoju?”. Odsetek odpowiedzi ankietowych rodziców dzieci 7-letnich wskazujących na występowanie szumów usznych u 12,9\% dzieci oraz rodziców dzieci 12-letnich potwierdzających występowanie szumów usznych u $16,6 \%$ dzieci okazał się niższy w porównaniu z odpowiedziami uzyskanymi bezpośrednio od dzieci. Analiza odpowiedzi dzieci na pytanie o odczuwanie szumów usznych wykazała, że 29,3\% siedmiolatków oraz 34,5\% dzieci dwunastoletnich potwierdza słyszenie szumów usznych. Za bardziej wiarygodne uznano wyniki uzyskane na podstawie odpowiedzi ankietowych rodziców. Powyższe opracowanie jak dotychczas jest badaniem, które objęło zasięgiem największą liczbę dzieci [21].

W tym samym roku Mahboubi ocenił występowanie, w ciągu 12 miesięcy poprzedzających badanie, szumów usznych trwających powyżej 5 minut i odczuwanych jako dzwonienie i brzęczenie u młodzieży w wieku od 12 do 19 lat. Występowanie szumów usznych ocenił na poziomie $7,5 \%$. Badania zostały przeprowadzone w dwóch grupach wiekowych. W grupie młodszej, w wieku od 12 do 15 lat, szumy zgłosiło 5,7\% dzieci, natomiast w grupie starszej, w wieku od 17 do 19 lat, szumy stwierdzono u 9,5\% młodych ludzi. W obu badanych grupach wiekowych szumy występowały częściej wśród płci żeńskiej, u osób palących papierosy lub przebywających w środowisku osób palących oraz u dzieci pochodzących $\mathrm{z}$ rodzin o niższych dochodach w przeliczeniu na członka rodziny. Szumy uszne obserwowano częściej wśród dzieci i młodzieży narażonej na hałas zarówno zawodowy, jak i rekreacyjny. Ten sam badacz dodatkowo wyodrębnił podgrupę odczuwającą przewlekle dokuczliwe szumy przez co najmniej 3 miesiące. Występowanie przewlekłych szumów usznych stwierdził u 4,7\% badanych [22].

Park w 2014 r. po przebadaniu 3037 osób w wieku od 12 do 19 lat stwierdził występowanie szumów usznych u 17,7\%. Częstość występowania szumów usznych wzrastała wraz z wiekiem badanych. Większy odsetek występowania stwierdzono wśród dziewcząt. Większość badanych $(84,3 \%)$ nie odczuwała żadnego dyskomfortu z powodu szumów usznych. Tylko 0,6\% młodych ludzi skarżyło się na dokuczliwe szumy. Nie stwierdzono zależności pomiędzy odczuwanymi szumami a wskaźnikiem BMI, spożyciem alkoholu, mniejszymi miesięcznymi dochodami w przeliczeniu na członka rodziny czy narażeniem na stres. Potencjalnymi czynnikami ryzyka okazały się: niedobory snu, krótkotrwałe narażenie na hałas, występowanie szumów usznych u matki [23].

W 2015 r. Piotrowska przedstawiła wyniki badań oceniające występowanie szumów usznych u dzieci w wieku 7 i 12 lat uczęszczających do szkół w Warszawie. Dane ankietowe zostały zebrane podczas realizacji Programu Przesiewowych Badań Słuchu wśród dzieci w wieku szkolnym. $\mathrm{W}$ porównaniu $\mathrm{z}$ badaniami prowadzonymi w latach 2011 i 2013 w Polsce opublikowanymi przez Raj-Koziak, istotną innowacją była zmieniona formuła pytania, a w zasadzie 
Tabela 1. Częstość występowania szumów usznych wśród dzieci

Table 1. The prevalence of tinnitus in children

\begin{tabular}{|c|c|c|c|c|c|c|c|c|}
\hline \multirow{3}{*}{ Autor } & \multirow{3}{*}{ Rok } & \multirow{3}{*}{$\mathbf{N}$} & \multirow{3}{*}{ Wiek dzieci } & \multicolumn{5}{|c|}{ Częstość występowania szumów usznych } \\
\hline & & & & \multirow{2}{*}{ Ogólnie } & \multicolumn{2}{|c|}{ Słuch } & \multirow{2}{*}{ Stałe } & \multirow{2}{*}{ Okresowe } \\
\hline & & & & & Prawidłowy & Niedosłuch & & \\
\hline Nodar & 1972 & 2000 & $10-18$ & & $13,3 \%$ & $58,6 \%$ & & \\
\hline Mills & 1986 & 93 & $5-16$ & & $29 \%$ & & & \\
\hline Graham & 1987 & 158 & $12-18$ & & & $49 \%$ & $47,3 \%$ & $1,7 \%$ \\
\hline Viani & 1989 & 102 & $6-17$ & & & $23,5 \%$ & & \\
\hline Stouffer & 1992 & 161 & $7-12$ & & $6 / 13 \%$ & $24 / 29 \%$ & & \\
\hline Anst & 2002 & 1420 & $7-12$ & $7 \%$ & & & $1,2 \%$ & $5,8 \%$ \\
\hline Holgers & 2003 & 964 & 7 & $12 \%$ & $13 \%$ & $8,8 \%$ & & \\
\hline Coelho & 2007 & 506 & $5-12$ & $37 \%$ & & & & \\
\hline Savastano & 2007 & 1100 & $6-16$ & $34 \%$ & & & $27 \%$ & $7 \%$ \\
\hline Aksoy & 2007 & 1020 & $6-16$ & $15,1 \%$ & & & $1 \%$ & $14,1 \%$ \\
\hline \multirow{3}{*}{ Bulbul } & 2009 & 428 & $11-13$ & $33,5 \%$ & & & & \\
\hline & & & $13-15$ & $36,8 \%$ & & & & \\
\hline & & & $16-18$ & $31,5 \%$ & & & & \\
\hline Juul & 2012 & 756 & 7 & & $27 \%$ & $50 \%$ & & \\
\hline Kim & 2012 & 928 & $10-12$ & & & & $4,4 \%$ & $46,9 \%$ \\
\hline \multirow[t]{3}{*}{ Raj-Koziak } & 2013 & 118005 & 7 & $12,9 \%$ & $12 \%$ & $19 \%$ & $1,1 \%$ & $11,8 \%$ \\
\hline & & 23335 & 12 & $16,6 \%$ & $16 \%$ & $25,1 \%$ & $1,5 \%$ & $15,1 \%$ \\
\hline & 2013 & 1792 & (1) $12-15$ & $5,7 \%$ & & & $3,0 \%$ & $2,7 \%$ \\
\hline \multirow[t]{2}{*}{ Mahboubi } & & 1728 & (2) 16-19 & $9,5 \%$ & & & $6,5 \%$ & $2,5 \%$ \\
\hline & & & $(1)+(2)$ & $7,5 \%$ & & & & \\
\hline \multirow[t]{2}{*}{ Park } & 2014 & 3047 & $12-19$ & $17,7 \%$ & & & & \\
\hline & 2015 & 7281 & (1) 7 & $6,9 \%$ & $6,6 \%$ & $9,4 \%$ & & \\
\hline \multirow[t]{2}{*}{ Piotrowska } & & 7918 & (2) 12 & $6,1 \%$ & $4,8 \%$ & $8,8 \%$ & & \\
\hline & & & $(1)+(2)$ & $6,0 \%$ & $5,6 \%$ & $9,0 \%$ & $1,2 \%$ & $4,8 \%$ \\
\hline
\end{tabular}

odpowiedzi na pytanie, na temat odczuwanych szumów usznych, skierowanego do dzieci. Pytanie brzmiało następująco: „Czy w ciągu ostatnich 6 miesięcy odczuwałeś/aś dźwięki w uszach czy głowie takie jak: dzwonienie brzęczenie lub syczenie, które pojawiło się bez uchwytnej przyczyny?". W odpowiedziach udzielanych przez dzieci wprowadzono określony limit czasu odczuwania szumów usznych. Dzieci miały do wyboru jedną z czterech możliwości. Za odpowiedzi negatywne uznano brak słyszenia szumów lub ich słyszenie przez czas krótszy niż 5 minut. Szumy słyszane ciągle oraz przez okres dłuższy niż 5 minut zostały zaliczone do kategorii odpowiedzi pozytywnych. Szumy uszne stwierdzono u 6\% dzieci, przy czym częściej występowały w grupie 7-latków w porównaniu z 12-latkami. W obu grupach wiekowych stwierdzono istotne statystycznie częstsze występowanie szumów w grupie dzieci z niedosłuchem. Szumy stałe stwierdzono u $20 \%$ dzieci odczuwających szumy uszne [24].

W tabeli 1 przedstawiono chronologicznie wyniki badań oceniających częstość występowania szumów usznych u dzieci.

\section{Dyskusja}

Publikowane dotychczas w piśmiennictwie wyniki na temat częstości występowania szumów usznych u dzieci różnią się między sobą w szerokim zakresie. Według Coelho na szeroki rozrzut prezentowanych wartości oceniających częstość występowania szumów usznych u dzieci składa się wiele czynników: różne kryteria użyte do zdefiniowania pojęcia szumów usznych oraz oceniające stan słuchu, zróżnicowany wiek badanych grup dzieci, różnorodność ankiet używanych do zbierania wywiadu $\mathrm{z}$ dzieckiem, różne procedury statystyczne stosowane do opracowania wyników. Czynniki behawioralne, takie jak związane z zaburzeniami emocjonalnymi, czy też hałas jako czynnik środowiskowy mogą również wpływać na rezultaty badań [17].

W piśmiennictwie medycznym nie ma zgodności, w jakim wieku pacjent przestaje być dzieckiem i wchodzi w wiek dorosły. W Polsce wiek 18 lat uznaje się za początek okresu dorosłości, ale w innych krajach stosuje się odmienne normy, np. w Anglii osoba po ukończeniu 16 roku życia uznawana jest za dorosłą. Według Savastano wiarygodne 
informacje na temat szumów usznych można uzyskać od dziecka około 8 roku życia [2]. W cytowanych publikacjach grupy badawcze różniły się między sobą średnią wieku oraz badanymi przedziałami wiekowymi. Nodar, podobnie jak Graham, Viani, Bulbul, Mahboubi i Park, oceniał szumy uszne u dzieci starszych, pomiędzy 10 a 19 rokiem życia $[6,8,9,22,23]$. Stouffer, Holgers, Coelho, Juul, Raj-Koziak i Piotrowska badali dzieci młodsze, w wieku od 6 do 12 lat [11,15-17, 20,21,24]. Niektórzy badacze oceniali problem szumów usznych w szerokim przedziale wiekowym - od 6 do 16 roku życia $[9,18]$. Dane dotyczące występowania szumów usznych zbierane są zazwyczaj na podstawie wywiadu przeprowadzanego $\mathrm{z}$ dzieckiem, jak w przypadku danych opublikowanych przez Stouffera, Coelho, Savastano oraz Ansta [11,17,2,14]. Analiza wyników badań ankietowych stanowi alternatywny sposób pozyskiwania danych na temat częstości występowania szumów usznych u dzieci i może być przeprowadzona jako badanie kohortowe [6] lub przekrojowe [15,18-23]. Liczebności badanych grup dzieci poddanych ocenie pod kątem odczuwania szumów usznych u cytowanych autorów różnią się znacznie między sobą i wynoszą od kilkuset do kilkunastu tysięcy: Nodar 2000 dzieci, Graham - 158 dzieci, Viani -102 dzieci, Stouffer - 161 dzieci, Holgers - 964 dzieci, Savastano - 1100 dzieci, Anst - 1420 dzieci, Coelho - 506 dzieci, Juul - 756 dzieci $[6,8,9,11,15,2,14,17,16]$. Autorzy publikujący w ciągu ostatnich 3 lat opisują wyniki badań przeprowadzonych na grupach liczących powyżej 3000 [22-24]. Mahboubi szumy trwające powyżej 5 minut i dłużej odczuwane w ciągu ostatnich 3 miesięcy, stwierdzone grupie 7,5\% badanych w wieku od 12 do 19 lat, odnosi jako reprezentatywne dla grupy 2,5 miliona nastolatków w USA [22].

Częstość występowania szumów usznych u dzieci prawidłowo słyszących według różnych autorów wyniosła: wg Nodara - 13,3\%, wg Millsa - 29\%, wg Holgers - 13\%, wg Juul - 27\%, wg Raj-Koziak - 12\% u 7-latków i 16\% u 12-latków $[6,7,11,15,16,21]$. Piotrowska w swoich badaniach $w$ grupie dzieci prawidłowo słyszących stwierdziła szumy uszne u 5,6\% $\mathrm{z}$ nich, co $\mathrm{w}$ porównaniu $\mathrm{z}$ innymi autorami stanowi najniższy odsetek [24]. W grupie dzieci niedosłyszących odsetek występowania szumów usznych według większości autorów jest wyższy niż w grupie dzieci prawidłowo słyszących i wynosi: wg Nodara $58,6 \%$, wg Grahama - 49,0\%, wg Viani - 23,5\%, wg Drukiera - 33,0\%, wg Stouffera - 24-29\%, wg Piotrowskiej - 9\% [6,8-11,24]. Odwrotną zależność stwierdziła Holgers. W prowadzonych przez nią badaniach dzieci z niedosłuchem zgłaszały szumy rzadziej niż dzieci prawidłowo słyszące [18]. W badaniach Parka i Mahboubi różnice w częstości występowania szumów usznych wśród dzieci prawidłowo słyszących oraz niedosłyszących okazały się statystycznie nieistotne $[22,23]$.

Autorzy, którzy w pytaniu o odczuwanie szumów usznych uwzględnili czynnik czasu (Stouffer, Piotrowska, Mahboubi), otrzymali niższe wyniki - od $6 \%$ do 7,5\% - niż badacze (Nodar, Holgers, Coelho, Savastano, Raj-Koziak, Park), którzy pytali tylko o słyszenie szumów usznych, nie określając czasu ich trwania - ich wyniki wahały się w zakresie od 13\% do 37\% [11,24,22,6,15,17,2,21,23].

Dokładne poznanie problemu szumów usznych u dzieci wydaje się szczególnie istotne nie tylko ze względu na ich przyczyny, które mogą być identyczne jak u dorosłych (tj. urazy głowy, guzy nerwu VIII, przyczyny metaboliczne oraz naczyniowe), lecz także z uwagi na fakt, że szumy mogą negatywnie wpływać na stan psychiczny dzieci oraz być powodem gorszych wyników w nauce. Kim ocenił współwystępowanie szumów usznych oraz zaburzeń lękowych u dzieci w wieku 10-12 lat, które odpowiadały na pytania zawarte w kwestionariuszu THI (Tinnitus Handicap Inventory), rutynowo stosowanym u osób dorosłych do oceny dokuczliwości szumów usznych oraz na wizualnej skali analogowej VAS (Visual Analoque Scale). Kolejne dwa kwestionariusze oceniały poziom lęku: SAIC (State Anxiety Inventory for Children) oraz TAIC (Trait Anxiety Inventory for Children). Wśród 924 badanych dzieci wyniki testu TAIC wskazywały na statystycznie wyższy poziom lęku wśród dzieci, które szumy uszne odczuwały częściej w porównaniu z grupą dzieci odczuwających szumy uszne rzadziej. Bartnik oceniała z kolei dokuczliwość szumów usznych za pomocą wizualnej skali analogowej i stwierdziła, że stanowią one istotny problem u $41,3 \%$ spośród 143 badanych dzieci, dla których średnia wieku wynosiła 14,4 lat [26]. Według Holgers pośród dzieci, które zgłosiły się w celu leczenia szumów usznych i zostały poddane ocenie z wykorzystaniem Skali lęku i depresji HADS (Hospital Anxiety and Depression Scale), u 33\% badanych wykazano zaburzenia emocjonalno-lękowe, a u 14,5\% istniało prawdopodobieństwo wystąpienia depresji [28]. Coelho w swoich badaniach stwierdziła, że występowanie szumów usznych powoduje rozdrażnienie u $17,0 \%$ badanych dzieci oraz wpływa negatywnie na aktywności życiowe takie jak uprawianie sportu [17]. Kentish opisał profil psychologiczny małego dobrze słyszącego pacjenta z dokuczliwymi szumami usznymi - dzieci z prawidłowym progiem słyszenia odczuwały większy niepokój z powodu szumów usznych w porównaniu z dziećmi $\mathrm{z}$ niedosłuchem współistniejącym z szumami usznymi [29]. Według Kentisha i Coelho szumy uszne u dzieci mogą być przyczyną uzyskiwania gorszych wyników w nauce $[17,63]$.

\section{Wnioski}

Mimo coraz większej liczby publikacji nadal trudno jest jednoznacznie ocenić, czy szumy uszne stanowią istotny problem w populacji dziecięcej.

Przyjęcie konsensusu definiującego pojęcie stałych szumów usznych u dzieci ułatwiłoby ocenę tego problemu $\mathrm{w}$ populacji dziecięcej.

Publikacja powstała $w$ zwiazku $z$ realizacja projektu pn. „Zintegrowany system narzędzi do diagnostyki i telerehabilitacji schorzeń narząów zmysłów (słuchu, wzroku, mowy, równowagi, smaku, powonienia)" INNOSENSE, wspólfinansowanego przez Narodowe Centrum Badań i Rozwoju w ramach Programu STRATEGMED. 


\section{Piśmiennictwo:}

1. Baquley DM, Mc Ferran DJ. Tinnitus in childhood. Int J of Otorhinolaryngol, 1999; 49: 99-105.

2. Savastano M. Characteristics of tinnitus in childhood. Eur J Pediatr, 2007; 166(8): 797-801.

3. Thomas CH. Physical aspects of tinnitus. J Laryngol, 1938; 3 : $68-78$.

4. Venters RS. Discussion on tinnitus aurium. Proc Roy Soc Med, 1953; 46: 825-29.

5. Reed GF. An audiometric study of 200 cases of subjective tinnitus. Arch Otolaryngol, 1960; 71: 84-104.

6. Nodar RH. Tinnitus aurium in school age children: a survey. J Aud Res, 1972; 12: 133-35.

7. Mills RP, Albert DM, Brain CE. Tinnitus in childhood. Clin Otolaryngol. Allied Sci, 1986; 11(6): 431-34.

8. Graham JM, Butler J. Tinnitus in children. J Otolaryngol Otol, 1984 (Suppl.); 2009; 236-41.

9. Viani LG. Tinnitus in children with hearing loss. J of Laryngol and Otol, 1989; 103: 1142-45.

10. Drukier GS. The prevalence and characteristics of tinnitus with profound sensorineural hearing impairment. Am Ann Deaf, 1989; 134: 260-64.

11. Stouffer J i wsp. Tinnitus in normal hearing and hearing-impaired children. In IV International Tinnitus Seminar. Kugler Publications. Bordeaux, 1992.

12. Bartnik G, Fabijańska A, Raj-Koziak D. Szumy uszne i nadwrażliwość słuchowa u dzieci. Audiofonologia, 2000; 18(1): 159-65.

13. Borawska B, Bartnik G, Raj-Koziak D, Fabijańska A, Skarżyński H, Mrówka M. Szumy uszne i nadwrażliwość słuchowa u dzieci w materiale Kliniki Szumów Usznych IFIPS w Warszawie. Audiofonologia, 2003; 23: 119-25.

14. Anst G. Tinnitus in childhood. Int Tinnitus J, 2002; 8(1): 20-26.

15. Holgers KM. Tinnitus in 7-year-old children. Eur. J. Pediatr, 2003; 162(4): 276-78.

16. Juul J, Barrenäs M-L, Holgers K-M. Tinnitus and hearing in 7-year-old children. Arch Dis Child. 2012; 97(1): 28-30.
17. Coelho CB, Sanchez TG, Tyler RS. Tinnitus in children and associated risk factors. Prog Brain Res., 2007; 166: 179-91.

18. Aksoy S. i wsp. The extent and level of tinnitus in children of central Ankara. Int J Pediatr Otolaryngol, 2007; 71(2): 263-68.

19. Bulbul SF, Muluk NB, Cakir EP, Tufan E. Subjective tinnitus and hearing problems in adolescens. Int J Pediatr Otolaryngol, 2009; 73(8): 1124-31.

20. Raj-Koziak D, Piłka A, Bartnik G, Fabijańska A, Kochanek K, Skarzyński H. Ocena częstości występowania szumów usznych wśród 7-latków w Polsce wschodniej. Otolaryngol Pol, 2011; 65(2): 106-109.

21. Raj-Koziak D, Skarżyński H, Kochanek K, Fabijańska A. Ocena częstości występowania szumów usznych u dzieci w Polsce. Otolaryngol Pol, 2013; 67(3): 149-53.

22. Mahboubi H, Oliaei S, Kiumehr S, Dwabe S, Djalilian HR. The prevalence and characteristics of tinnitus in the youth population of the United States. Laryngoscope, 2013; 123, 2001-8.

23. Park B, Choi HG, Lee HJ, An SY, Kim SW, Lee JS i wsp. Analysis of the prevalence of and risk factors for tinnitus in a young population. Otol Neurotol, 2014; 35, 1218-22.

24. Piotrowska A, Raj-Koziak D, Lorens A, Skarżyński H. Tinnitus reported by children aged 7 and 12 years. Int J Pediatr Otolaryngol, 2015; 79: 1346-50.

25. Kim YH, Jung HJ, Kang SI, Park KT, Choi J, Oh S i wsp. Tinnitus in children: Association with stress and trait anxiety. Laryngoscope, 2012; 122: 2279-84.

26. Bartnik G, Stępień A, Raj-Koziak D, Fabijańska A, Niedziałek I, Skarżyński H. Troublesome tinnitus in children: epidemiology, audiological profile and preliminary results of treatment. Int J of Pediatrics, 2012; 1-5.

27. Holgers KM, Petterson B. Noise exposure and subjective hearing symptoms among school children in Sweden. Noise Health, 2005; 7(27): 27-37.

28. Kentish RC, Cocker SR, Mc Kenna L. Children's experience of tinnitus: preliminary survey of children presenting to psychology department. Br J Audiol, 2000; 34(6): 335-40. 